\title{
FOREST FIRE ANALYSIS AND CLASSIFICATION BASED ON A SERBIAN CASE STUDY
}

Tin Lukić, Predrag Marić, Ivana Hrnjak, Milivoj B. Gavrilov, Dragan Mladjan, Matija Zorn, Blaž Komac, Zoran Milošević, Slobodan B. Marković, Dušan Sakulski, Andries Jordaan, Jasmina Đorđević, Dragoslav Pavić, Rastislav Stojsavljević

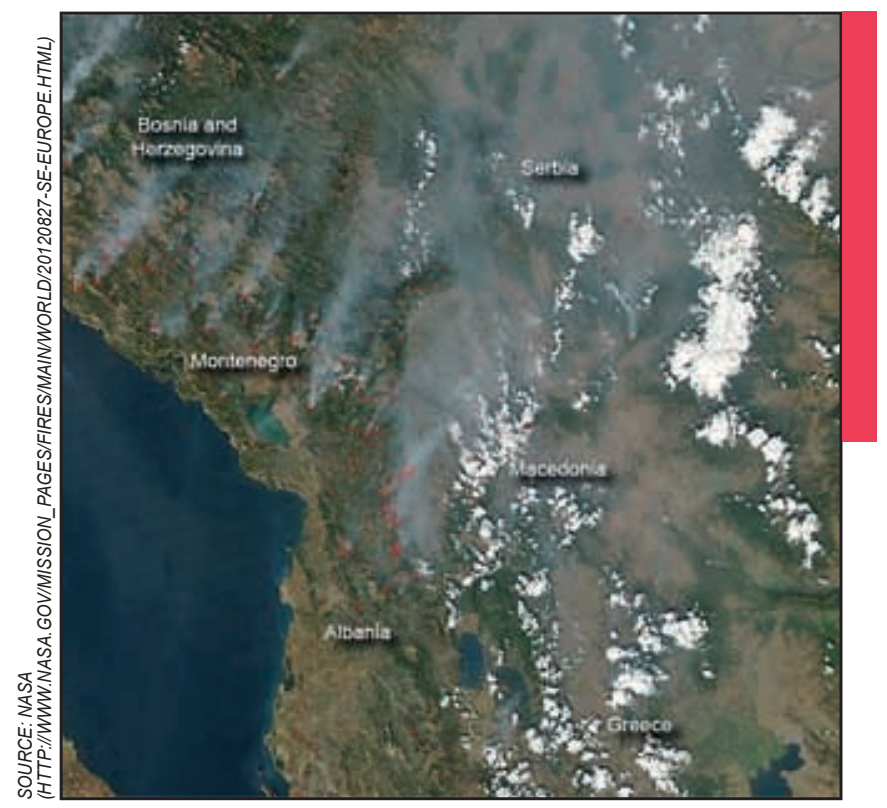

Aqua/MODIS Forest Fires observations in South-East Europe, August $26^{\text {th }} 2012$. 


\section{Forest fire analysis and classification based on a Serbian case study}

DOI: http://dx.doi.org/10.3986/AGS.918

UDC: 91:614.841.42:630(497.11)

COBISS: 1.01

ABSTRACT: A recent forest fire in the Republic of Serbia is discussed concerning classification, legislative framework and fire management, giving a detailed analysis of the forest fire occurrence. Analysing past and predicting future fires are crucial for policy development and forest management practices to prevent and mitigate fires. Fire hazard is discussed through several fire protection and prevention legislative documents. The nonparametric Mann-Kendall test was used to analyse resent forest fire data in an attempt to find causality in occurrences and frequency. The meteorological data and fire statistics provided by the Serbian Hydro-meteorological Service and the Ministry of Interior/Sector for Emergency Management of the Republic of Serbia were used to calculate the Forest Fire Weather Indices, along with deficit or surplus of precipitation for the case study of Tara Mountain. The paper highlights the need for better hierarchical classification of fire hazards and its harmonisation along with standardisations presented by leading international research institutions. A significant correlation between meteorological parameters and forest fire occurrence was found. This opens a possibility for further investigation and analysis of geophysical and anthropogenic driven factors that can influence disaster occurrence.

KEY WORDS: geography, natural hazards, forest fires, classification, forest fire weather indices, Tara mountain, Serbia

The article was submitted for publication on October $10^{\text {th }}, 2014$.

\section{ADDRESSES:}

\section{Tin Lukić, Ph.D.}

Department of geography, tourism and hotel management

Faculty of sciences, University of Novi Sad

Trg Dositeja Obradovića 3, RS - 21000 Novi Sad, Serbia

E-mail: tin.lukic@dgt.uns.ac.rs

\section{Predrag Marić, Ph.D.}

Ministry of interior, Sector for emergency management of the Republic of Serbia

Kneza Miloša 101, RS - 11000 Belgrade, Serbia

E-mail: predrag.maric@kpa.edu.rs

\section{Ivana Hrnjak, M.Sc.}

Department of geography, tourism and hotel management

Faculty of sciences, University of Novi Sad

Trg Dositeja Obradovića 3, RS - 21000 Novi Sad, Serbia

E-mail: ivana.hrnjak2112@gmail.com

\section{Milivoj B. Gavrilov, Ph.D.}

Department of geography, tourism and hotel management

Faculty of sciences, University of Novi Sad

Trg Dositeja Obradovića 3, RS - 21000 Novi Sad, Serbia

E-mail: milivoj.gavrilov@yahoo.com

\section{Dragan Mladjan, Ph.D.}

Academy of criminalistic and police studies

Cara Dušana 196, RS - 11080 Zemun, Belgrade, Serbia

E-mail: dragan.mladjan@kpa.edu.rs 


\section{Matija Zorn, Ph.D.}

Anton Melik geographical institute

Research centre of the Slovenian academy of sciences and arts

Gosposka ulica 13, SI - 1000 Ljubljana, Slovenia; E-mail: matija.zorn@zrc-sazu.si

\section{Blaž Komac, Ph.D.}

Anton Melik Geographical Institute

Research Centre of the Slovenian Academy of Sciences and Arts

Gosposka ulica 13, SI - 1000 Ljubljana, Slovenia; E-mail: blaz.komac@zrc-sazu.si

\section{Zoran Milošević, Ph.D.}

Department of geography, tourism and hotel management

Faculty of sciences, University of Novi Sad

Trg Dositeja Obradovića 3, RS - 21000 Novi Sad, Serbia/

and

Faculty of engineering and physical science, University of Surrey

Guildford Surrey GU2 7XH, United Kingdom; E-mail: ZMilosevic@kbcat.com

\section{Slobodan B. Marković, Ph.D.}

Department of geography, tourism and hotel management Faculty of sciences, University of Novi Sad

Trg Dositeja Obradovića 3, RS - 21000 Novi Sad, Serbia; E-mail: slobodan.markovic@dgt.uns.ac.rs

\section{Dušan Sakulski, Ph.D.}

Department of environmental engineering and occupational safety and health

Faculty of technical sciences, University of Novi Sad

Trg Dositeja Obradovića 6, RS - 21000 Novi Sad, Serbia

and

Disaster management training and education centre (DiMTEC)

University of the Free State

205 Nelson Mandela drive park west, Bloemfontein, South Africa; E-mail: dsakulski2@me.com

\section{Andries Jordaan, Ph.D.}

Disaster management training and education centre (DiMTEC)

University of the Free State

205 Nelson Mandela drive park west, Bloemfontein, South Africa; E-mail: ajjrdn@gmail.com

\section{Jasmina Đorđević, Ph.D.}

Department of geography, tourism and hotel management

Faculty of sciences, University of Novi Sad

Trg Dositeja Obradovića 3, RS - 21000 Novi Sad, Serbia; E-mail: jasminadjordjevic@live.com

\section{Dragoslav Pavić, Ph.D.}

Department of geography, tourism and hotel management

Faculty of sciences, University of Novi Sad

Trg Dositeja Obradovića 3, RS - 21000 Novi Sad, Serbia; E-mail: dragoslav.pavic@dgt.uns.ac.rs

\section{Rastislav Stojsavljević, Ph.D.}

Department of geography, tourism and hotel management

Faculty of sciences, University of Novi Sad

Trg Dositeja Obradovića 3, RS - 21000 Novi Sad, Serbia; E-mail: ralegeo87@yahoo.com 


\section{Introduction}

While natural hazards present threat to humans and their environment, they do not necessarily result from natural and environmental processes and causes alone. Processes of interaction between natural and anthropogenic systems also bring about hazards. Improved understanding of these interactions alters our comprehension of natural hazards, shifting it from an area of pure natural phenomena to the domain of social and psychological occurrence (Lukić et al. 2013).

In the era of pronounced climate variability, understanding past and predicting future fire activity are scientific challenges crucial to the development and implementation of sustainable forest management practices and policies. However, such objectives are difficult to achieve in practice because existing meteorological data and general fire statistics are only available for a short period of time. Accordingly, uncertainties concerning future fire activity limit the range of variability and occurrence patterns that can be determined (Girardin et al. 2013).

Forests occupy an area of nearly 4 billion hectares, covering about $30 \%$ of Earth's land surface. Worldwide, more than 50,000 forest fires occur annually (Aleksić, Krstić and Jančić 2009), on average destroying more than 40 million hectares of forestry, claiming human casualties, and resulting in wildlife losses and displacement on approximately $400,000 \mathrm{~km}^{2}$ (Internet 1 ). Fire and heat not only destroy trees and plants, but change the forestry structure, forest biology and soil performance (Zhong, Fan and Wang 2000).

Different authors give different definitions of forest fires classification, while diverse legislations also classify it in their own terms (Subošić and Mlađan 2013). Harmonising the definition of forest fire hazards as an integral part of a wider natural hazard topic, would contribute to an improved understanding thereof, and hopefully lead to a more effective classification, identification, prediction, and mitigation.

The National fire protection association (NFPA) categorises fires by classes: A, B, C, D, K. According to this classification, forest fires belong to class A. In terms of hazard, NFPA classifies fire-prone areas as light (low), ordinary (moderate) or extra (high) hazardous (Internet 2).

Alexander (2008) proposed a rating methodology for fire hazard in forests and rural areas, to be used in fire management. The fire hazard class is derived from the Fire Weather Index (FWI) System as low; moderate; high; very high and extreme.

The Centre for research on the epidemiology of disasters (CRED) and Munich reinsurance company (Munich RE) with their respectable International databases - EM-DAT and NatCatSERVICE - treat forest fires as "wildfire « hazards (main-type) within the generic climatological hazard group (Below, Wirtz and Guha-Sapir 2009).

Markov, Jovičić and Ristić (2010) base their classification on the type of material burned, whereby forest fires are classified as underground and ground fires (burning roots, humus and peat); above-ground or low fires (burning the upper layer of organic forest litter and shrubs); treetop or high fires and a single tree fire.

\section{Forest fires in Serbia between legislation and application frameworks}

The forestry area in Serbia decreased from over 2,000,000 ha in 2001 to 1,962,335 ha in 2012, now covering $22.2 \%$ of the country's territory. State owned forests extend to over 927,773 ha and privately owned ones to $1,034,562$ ha (Statistical yearbook ... 2012).

Several fire protection and prevention documents address fire hazards. These acts cover systems of prevention, mitigation, protection, rescue and rehabilitation:

The Fire Protection and Prevention Act treats the fire hazard mainly as a physical phenomenon: $» A$ process of uncontrolled combustion that can threaten human health and lives, or cause other damages on a larger scale endangering material goods and environment « (Zakon ... 2009). There is no clear distinction between a forest fire hazard and a general fire hazard. This classification differs from the contemporary classification of natural hazards proposed by highly regarded institutions such as CRED or Munich RE (Table 1).

The Law on Emergencies of the Republic of Serbia defines a natural hazard as: »Phenomena of hydro-meteorological, geological or biological origin, caused by natural forces like: earthquakes, flooding, flash floods, heavy rains, lightning, hail, drought, rock falls and landslides, snowdrift and avalanches, extreme air temperatures, ice formation on water courses, epidemics of contagious diseases, epidemics of cattle-related contagious diseases, 
Table 1: Wild fire hazard classification within harmonized EM-DAT and NatCatSERVICE databases (adapted after Below, Wirtz and Guha-Sapir 2009).

\begin{tabular}{|c|c|c|c|c|}
\hline Hazard generic group & Hazard group & Hazard Main-Type & Hazard Sub-Type & Hazard Sub-sub Type \\
\hline Natural hazard & Climatological & Wild fire & $\begin{array}{l}\text { Forest fire } \\
\text { Land fires } \\
\text { (grass, scrub, bush etc.) }\end{array}$ & None \\
\hline
\end{tabular}

and occurrence of pests and other natural phenomena on a large scale that can threaten human health and lives, or cause other damages on a larger scale (Zakon ... 2009). The above mentioned classification of natural hazards doesn't deal with wild fire nor forest or land fires, again in contrast with the practices of CRED and Munich RE.

The National Strategy of Protection and Rescue in Emergencies of the Republic of Serbia (Nacionalna ... 2011) proposes a more detailed hierarchical classification of natural hazards, provides general data, including frequencies, and proposes monitoring and mitigation measures. An integral part of this Strategy is the document "Study on Economic Benefits of RHMS (Republic hydrometeorological service of Serbia) (Dimitrijević 2005) in which the authors observe that forest fires were not taken into account in the analysis of the vulnerability of weather-dependent economic sectors.

A clearer and a more uniform hazard classification in Serbia, aligned with international classifications (e.g. CRED and Munich RE), are prerequisites for improved standardisation, both legislative and applicative (Lukić et al. 2013).

\section{Forest fire trend analysis - general observation}

Two statistical tests, both widely used in environmental sciences (e.g. Hrnjak et al. 2014) are applied:

- Linear trending of fire hazards in Serbia in the period 2000/2001-2012;

- Fires trending based on Mann-Kendall test (Kendall 1938; Mann 1945; Gilbert 1987).

For the trend data processing, XLSTAT's statistical analysis software was employed (Internet 3). Furthermore, two hypotheses were tested:

- the null hypothesis: that there is no trend;

- the alternative hypothesis: that there is a trend for a given significance level. Probability was calculated to determine the level of confidence.

By calculating trends from the total number of fire hazards and forest fires, two equations were obtained:

$$
\begin{gathered}
\mathrm{y}=1286.2 x+12113_{,_{(1)}} p=0,005_{(2)} \\
\mathrm{y}=27.6 x+425.7,_{(1)} p=0,638_{(2)}
\end{gathered}
$$

where $y$ is either the total number of fires (in equation $(1)_{1}$ ), or the number of forest fires only in equation (2), $x$ is time in years, $p$ is probability and significance level $\alpha=0.05$ is the same in both cases.

Figure 1 illustrates equation (1) and shows a positive trend. As the value $(1)_{2}$ is lower than the significance level $\alpha=0.05$ the null hypothesis does not seem valid. The risk to reject the null hypothesis as true is less than $0.54 \%$. Conversely, there is a $99.46 \%$ confidence in a positive trend concerning total number of fires in Serbia.

This analysis is not entirely conclusive. Figure 1 shows the total number of fire hazards, irrespective of the cause, ranging from explosions to technical traffic interventions. It is difficult to determine if this positive linear trend was a result of improved reporting of fire occurrences, or of a genuine increase in their frequency. More extensive future research will be needed to clarify this.

Figure 2, produced from equation $(2)_{1}$, shows a positive trend in number of forest fires. However, as the value $(2)_{2}$ is greater than the significance level $(\alpha=0.05)$, one cannot reject the null hypothesis here. Hypothesis testing will prove whether this statement is true or not. The risk to reject the null hypothesis as true is $36.15 \%$. Although the number of forest fires increased noticeably, evaluation of the Mann-Kendall test estimates that there is no trend in the number of forest fires in Serbia with probability of 63.85\%. 


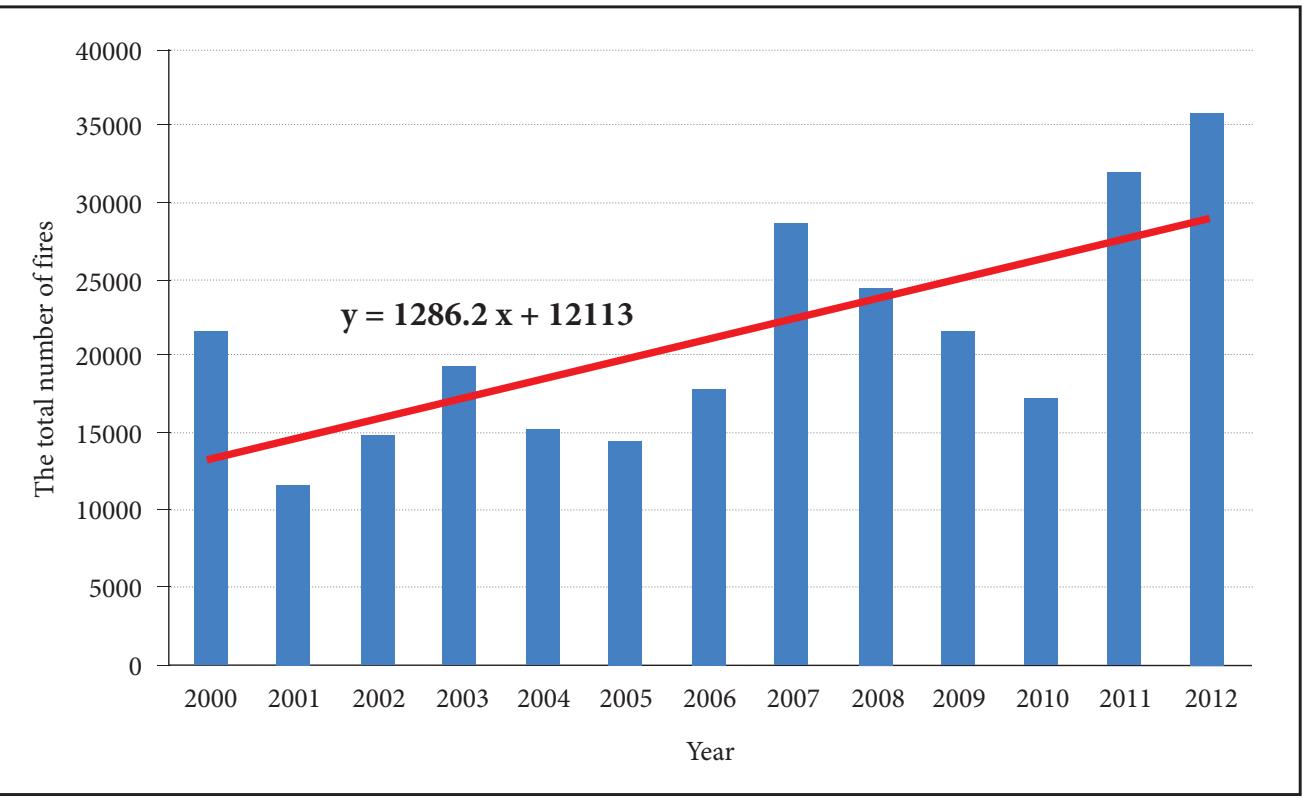

Figure 1: The total number of fires per year and linear trend curve from 2000 to 2012 in the Republic of Serbia.

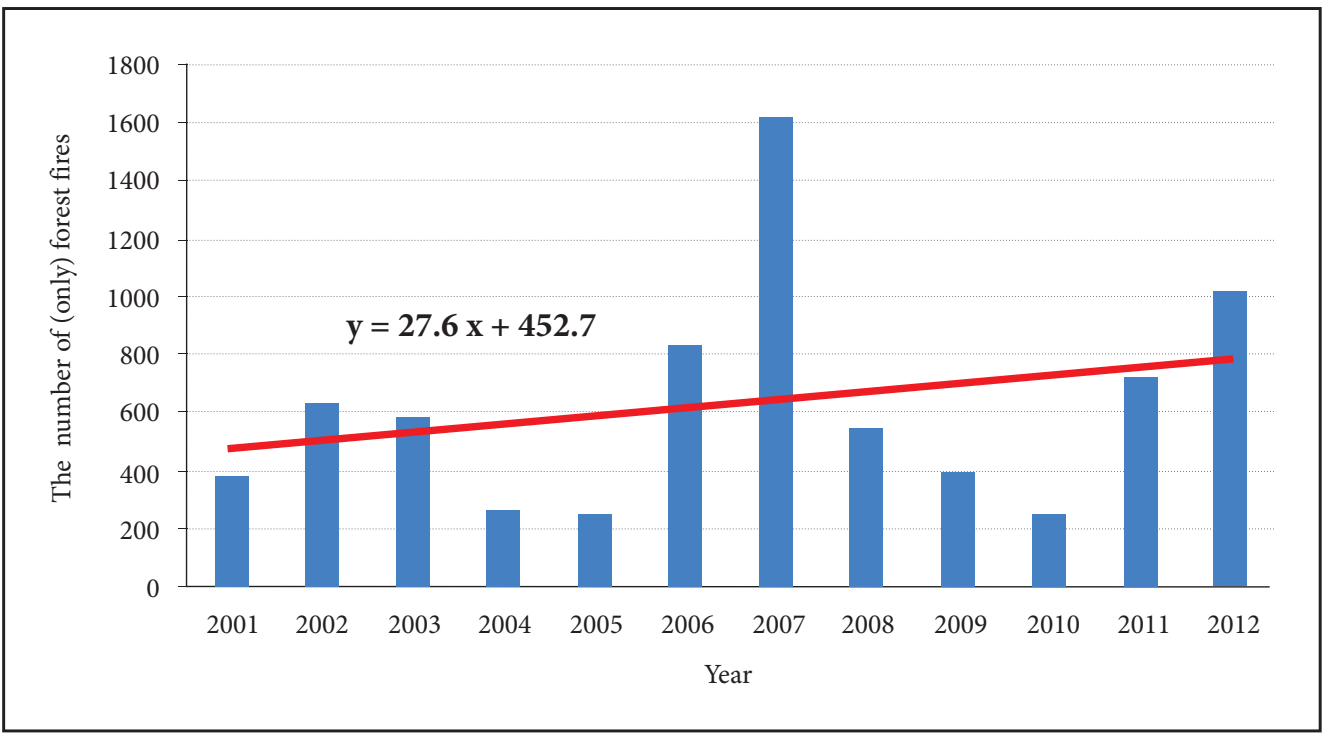

Figure 2: The number of (only) forest fires and linear trend curve from 2001 to 2012 in the Republic of Serbia.

According to Unkašević and Tošić $(2011 ; 2014)$, the last few decades in Europe is characterised by the steepest temperature increase since the beginning of the twentieth century. Extreme events related to intensive heating significantly affects natural hazards, socio-economic and health activities in Europe, as shown by the exceptional summer heat wave in 2003 (Schär et al. 2004; Trigo et al. 2005). During the summer of 2007, heat waves registered in the Balkan region (Founda and Giannakopoulos 2009), including Republic of Serbia 
(Unkašević and Tošić 2011), were primarily responsible for the largest fire-damaged area - the number of forest fires reached 1,600 (Figure 2). The year 2012 saw the longest heat waves during summer and the worst drought since the beginning of observations in Serbia, more than 1,000 forest fires occurred during that time (Figure 2). Data provided by the Ministry of interior, Sector for emergency management of the Republic of Serbia illustrates and corresponds to the findings of respectable authors mentioned above (Figures 1 and 2).

Authors recognise that factors other than geophysical (e.g. anthropogenic) must be taken into account when analysing the forest fires trends. The 2012 Tara Mountain case study shows that the frequency of forest fires, strongly influenced by climatic conditions, was above Serbian average.

\section{Forest fires in the Republic of Serbia 2012 - Tara Mountain Case Study}

The number of forest fires in Serbia increased to 1,028 in 2012, as registered by the Ministry of interior, Sector for emergency management of the Republic of Serbia. Their distribution is shown in Figure 3.

Quality data sets are available for the Tara mountain fires. Tara mountain is located in western Serbia with elevations between 1000 and 1500 meters. It forms a part of Serbian natural heritage and the forestry is highly sensitive to wild fires. The period from 23 August to 5 September 2012 was characterised by particularly high frequency of forest fire occurrences. Wildfires have burned 2,150 ha of mountain area, while the estimated damage costs reached up to 170,000 Euros.

\subsection{Risk indices}

A simple index for fire assessment is the Swedish Angstrom index (Willis et al. 2001). The index is based on the statistical relationships between the reported number of fire events and several antecedent-weather-related data. A weather-based index can only predict an area-averaged risk of fire, because the only input is obtained from the point measurements at a weather station (Onderka and Melicherčík 2009).

The Angstrom index is calculated from air temperature and relative humidity and provides an indication of the likely number of fires in a given day. The index, $I$, is calculated as follows (Skvarenina et al. 2003):

$$
I=\frac{R}{20}+\left(\frac{27-t}{10}\right)
$$

where $R$ is daily average relative humidity $(\%)$, and $t$ is daily average air temperature $\left({ }^{\circ} \mathrm{C}\right)$. As can be seen from the equation (3), $I$ decreases with the relative humidity and increases with the air temperature. A reduced index indicates a higher risk of fire. The use of the index for risk categorisation is shown in table 2.

In 1949, Nesterov (Shetinsky 1994) proposed a fire-risk rating index. This index establishes a range of discrete fire risk levels. The Nesterov Index is calculated as:

$$
N I=\sum_{i=1}^{w}\left(T_{i}-T_{i}^{d e w}\right) T_{i}
$$

where, $N I$ denotes the Nesterov index, $w$ is the number of days since the last rainfall exceeding $3 \mathrm{~mm}$ per day, $T_{i}$ is the temperature $\left({ }^{\circ} \mathrm{C}\right)$ on a given day, $T_{i}^{d e w}$ is the dew point temperature $\left({ }^{\circ} \mathrm{C}\right)$. The intrinsic characteristic of the Nesterov index is that it is reset to "zero" when daily rainfall exceeds $3 \mathrm{~mm}$ per day (Shetinsky 1994). The original risk levels proposed by Nesterov are shown in Table 2.

Table 2: The values of Angstrom index ( $($ and Nesterov index (N) translated into fire risk probability of fire (Skvarenina et al. 2003; Shetinsky 1994).

\begin{tabular}{llcc}
\hline Angstrom index ( $)$ & Probability of fire & Nesterov index (NI) & Probability of fire \\
\hline $1>4$ & Fire occurrence unlikely & $N /<300$ & No risk \\
$4<1<3$ & Fire occurrence unfavourable & $301<N /<1000$ & Low risk \\
$3.0<1<2.5$ & Fire conditions favourable & $1001<N /<4000$ & Medium risk \\
$2.5<1<2.0$ & Fire conditions more favourable & $4001<N /<10000$ & High risk \\
$\mid<2.0$ & Fire occurrence very likely & $N />10000$ & Extremely high risk \\
\hline
\end{tabular}




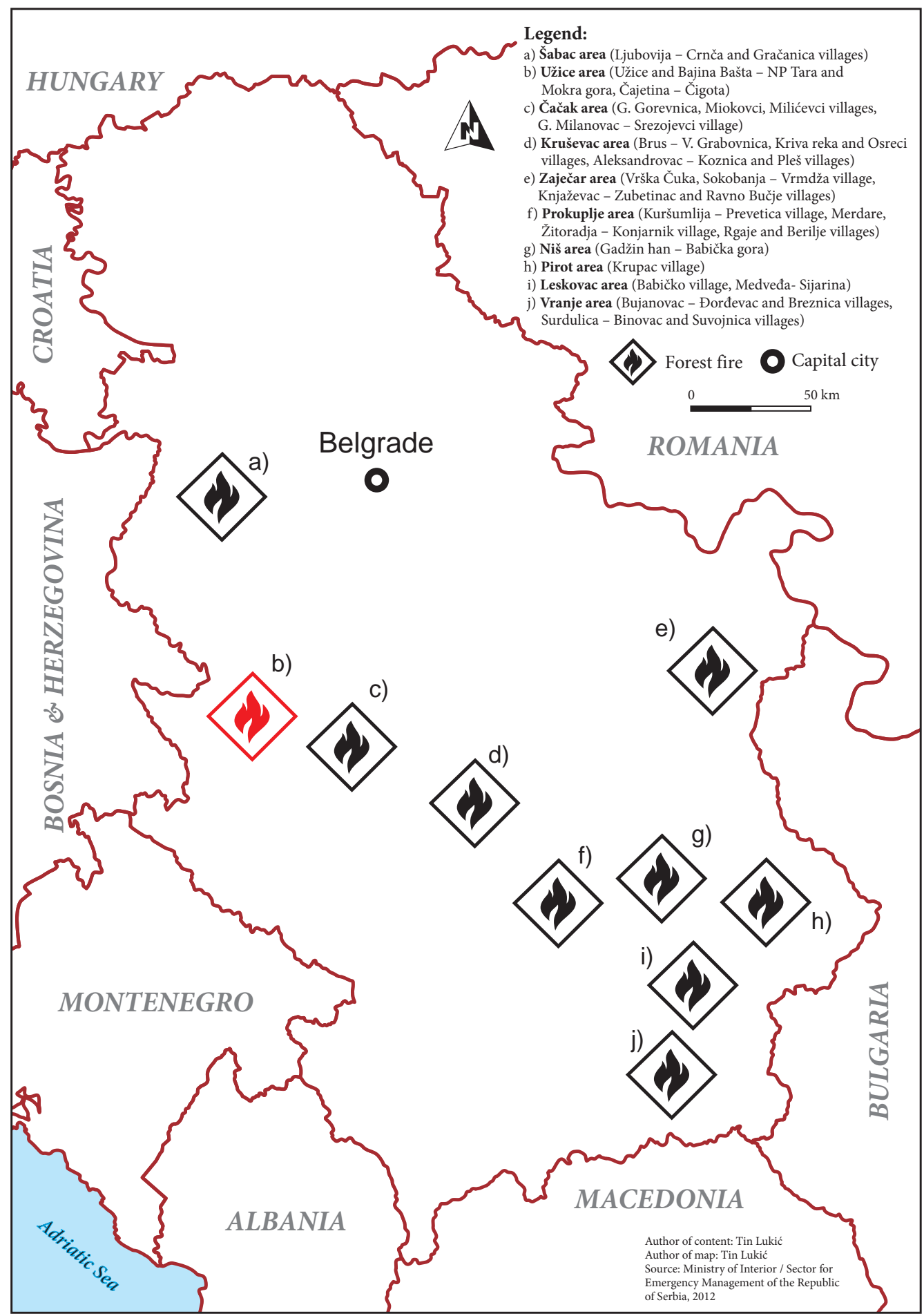

Figure 3: Distribution of main forest fires in the Republic of Serbia in 2012 (the case study area is under section »b» on the map - Užice area). 
According to the Angstrom index, the risk of fire was very high (values of the index lower than 2.0) for the period from 23 to 25 August, and on 31 August. The values of index ranging between 2 and 2.5 were registered on 26 August, 30 August and 1 September, and between 2.5 and 3.0 on 29 August, 2 and 4 September. On other dates, values of $I$ were above 3. The Nesterov index (NI) calculates only two risk levels for the period: »low risk « from 23 to 26 August and between 30 August and 1 September, and »no risk « in the periods from 27 to 29 August and 2 to 5 September.

Figure 4 shows the daily fluctuation of the Angstrom $(I)$ and Nesterov $(N I)$ indices during the observed period, as well as correlation between the two indices. The Pearson correlation coefficient is -0.97 . This shows that there is a correlation between the two indices, which could be expected considering that the same meteorological parameters are used in their calculation. The values of both indices are normalised; they range between 0 and 1 (the values of the Nesterov index are shown in a reversed order).

The values of the Angstrom and Nesterov indices can be correlated with the maximum temperature and relative humidity. The weather factors that could have an influence on forest fire indices are depicted in Figure 5.

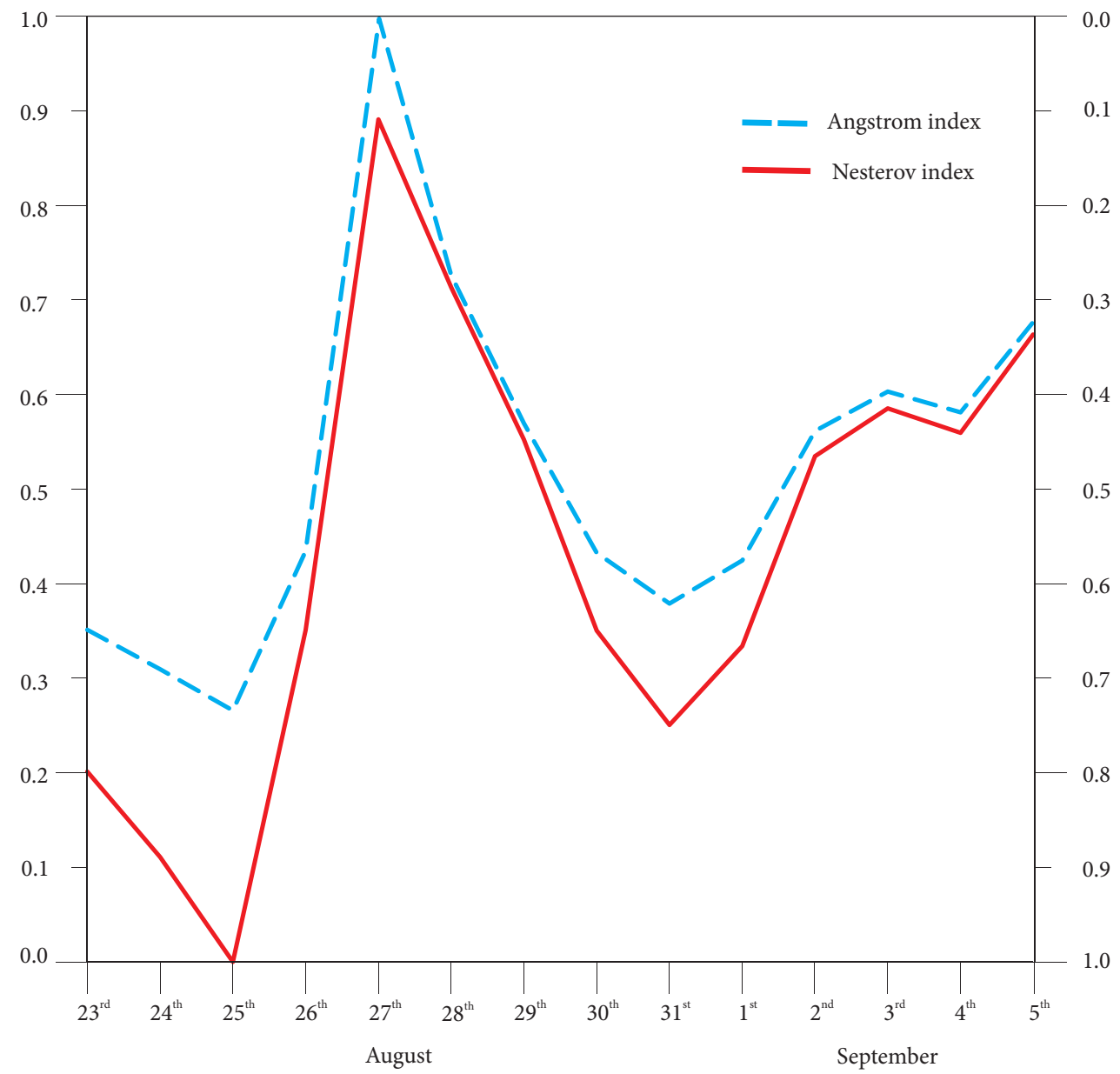

Figure 4: Correlation between Angstrom index ( $($ ) and Nesterov index (N). 


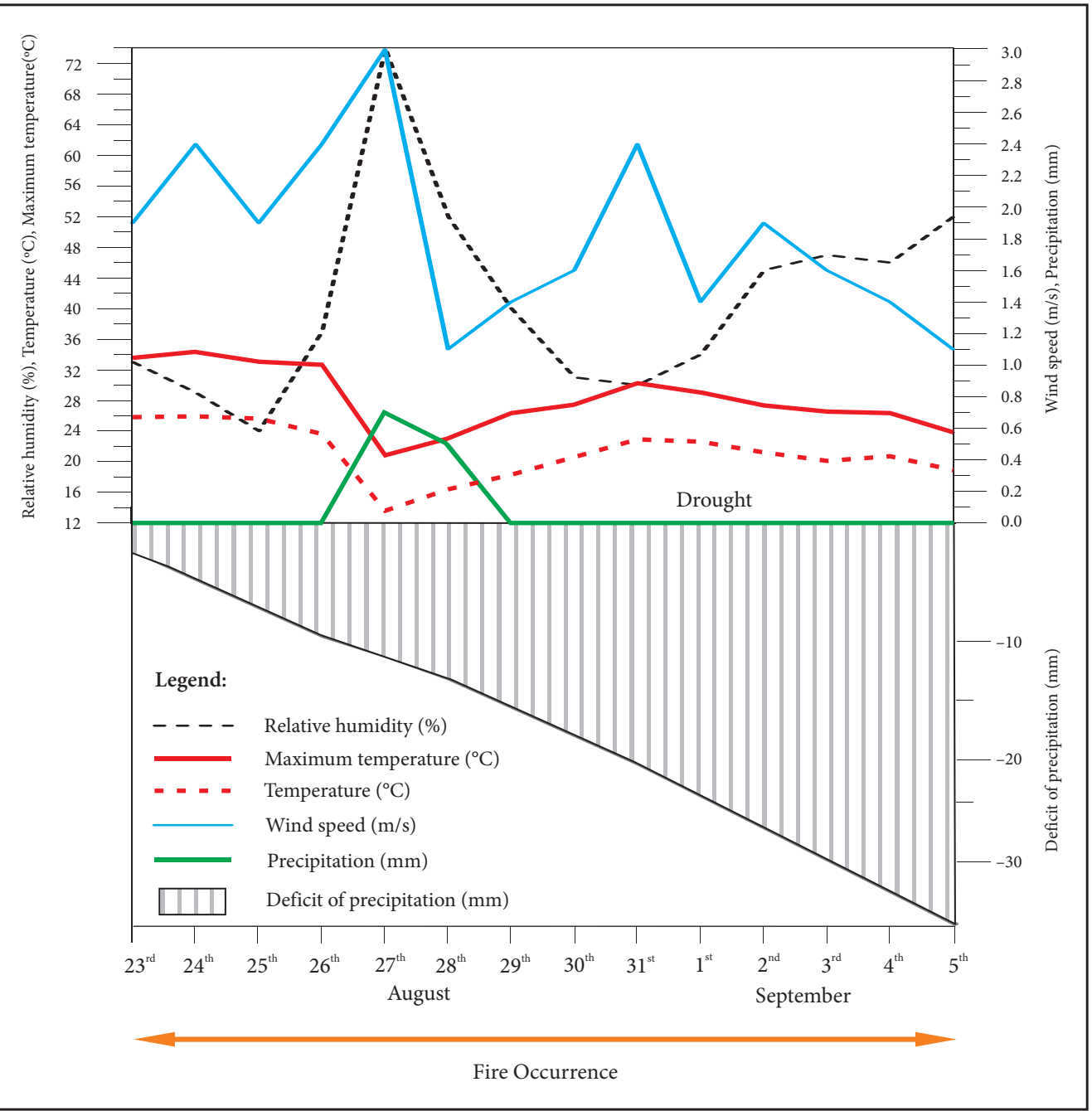

Figure 5: Graphical comparison of the deficit of precipitation, maximum temperature, daily temperature, wind speed and relative humidity in the Tara Region in 2012.

The Angstrom index presented the highest correlation of 0.98 with relative humidity. In addition, the correlation coefficient showed a highly negative correlation of -0.93 between maximum temperature and Angstrom fire index. This suggests that the values of Angstrom index $(I)$ will decrease with increased temperature and reduced relative humidity, in which cases fire occurrence would increase.

The results for the Nesterov index are similar. A high negative correlation between the Nesterov index $(N I)$ and relative humidity is recorded $(-0.93)$, while coefficient of correlation with maximum temperature shows a highly positive correlation (0.94).

\subsection{Precipitation}

Precipitation is another factor that affects fire risk. The percent of normal precipitation is a simple measure of rainfall in a location. Radinović (1979) proposed a method for calculating the deficit and surplus of precipitation (DSP) as a continuous function of time. 
The daily deficit and surplus of precipitation can be expressed by the equation:

$$
\left(D_{d}\right)_{i}=\left(T_{d}\right)+\sum_{i=1}^{n}\left(P_{d}+\bar{P}_{d}\right)_{i}
$$

where $T_{d}$ is daily deficit or surplus transferred from the previous month $(\mathrm{mm}), P_{d}$ is observed daily amount of precipitation $(\mathrm{mm}), \bar{P}_{d}$ is the expected quantity of daily precipitation $(\mathrm{mm}), i-1,2 \ldots$ and $n$ is representing days in a month (Ćurić and Živanović 2013).

The mean daily precipitation amounts $\left(\bar{P}_{d}\right)_{i}(i=1,2, \ldots, 365)$ were calculated by interpolation from the monthly mean precipitation amounts in the period of thirty years, between 1977 and 2006. These values are considered as the normally expected daily precipitation amounts (Table 3 ).

Table 3: Daily deficit of precipitation in the period from 23 August to 5 September.

\begin{tabular}{lccc}
\hline Date & $\left(P_{d}\right)_{i}$ & $\left(\bar{P}_{d}\right)_{i}$ & $\left(D_{d}\right)_{i}$ \\
\hline 23 August & 0 & 2,4 & $-2,4$ \\
24 August & 0 & 2,4 & $-4,8$ \\
25 August & 0 & 2,4 & $-7,2$ \\
26 August & 0 & 2,4 & $-9,6$ \\
27 August & 0,7 & 2,4 & $-11,3$ \\
28 August & 0,5 & 2,4 & $-13,2$ \\
29 August & 0 & 2,4 & $-15,6$ \\
30 August & 0 & 2,4 & -18 \\
31 August & 0 & 2,4 & $-20,4$ \\
1September & 0 & 2,7 & $-23,1$ \\
2September & 0 & 2,7 & $-25,8$ \\
3September & 0 & 2,7 & $-28,5$ \\
4 September & 0 & 2,7 & $-31,2$ \\
5September & 0 & 2,7 & $-33,9$ \\
\hline
\end{tabular}

A deficit of precipitation occurred through the entire analysed period (Figure 5). According to the definition, drought is a period of five or more successive days without or $\leq 0.3 \mathrm{~mm}$ precipitation (Bordy et al. 2004). The remainder periods are non-drought periods. Droughts can occur in both »deficit« and »surplus« precipitation periods. The likelihood of forest fire is greater during periods of low precipitation, but it is usually affected by other factors such as the presence of an ignition source.

\section{Conclusion}

Forest fires are considered in several legislative documents of Republic of Serbia. However, the authors maintain that a hierarchical classification of fire hazards with their sub-types, as suggested by CRED and Munich $\mathrm{RE}$, should be added to the legislative and other documents regulating the area of natural hazards. This would strengthen the legislative function and other frameworks used for risk management, and improve prevention and mitigation of forest fires.

Fire risk rating indices, based on empirical relationships between pre-event meteorological conditions and the number of observed fire outbreaks, can be a useful tool towards understanding forest fire hazards. The Angstrom index and Nesterov index were used to forecast the risk of fire occurrence in this study. These are perceived as tools that can assist forest managers to take preventive measures. The use of the indices, as a fire occurrence likelihood measure, was illustrated here in forest fire case study in the Tara region of Serbia. The results from this study can be used for creation of the platform for fire management operational framework that can be used as a tool for decision making prevention, detection and monitoring of forest fire hazards at both the local and national levels in the Republic of Serbia. Such a programme would be in line with the forest fire risk assessment and management practices that are currently being developed internationally. 
ACKNOWLEDGEMENT: This research paper is financed by Project 176020 of the Serbian Ministry of Education, Science and Technological Development.

\section{References}

Aleksić, A., Krstić, M. Jančić, G. 2009: Forest fires-ecological and economic problem in Serbia. Botanica SERBICA 33-2. Belgrade.

Alexander, M.E. 2008: Proposed revision of fire danger class criteria for forest and rural areas in New Zealand. Wellington.

Below, R., Wirtz, A., Guha-Sapir, D. 2009: Disaster category classification and peril terminology for operational purposes. Internet: http://www.cred.be/publication/disaster-category-classification-and-peril-terminologyoperational-purposes (10.12.2013).

Bordy, I., Fraedrich, K., Gerstengarbe, F. W., Werner, P. C., Sutera, A. 2004: Potential predictability of dry and wet periods: Sicily and Elbe-Basin (Germany). Theoretical and applied climatology 77-3. DOI: http://dx.doi.org/10.1007/s00704-003-0029-0

Ćurić, M., Živanović, S. 2013: Dependence between deficit and surplus of precipitation and forest fires. Disaster advances 6-6.

Dimitrijević, V. 2005: Study on economic benefits of RHMS of Serbia. Belgrade.

Founda, D., Giannakopoulos, C. 2009: The exceptionally hot summer of 2007 in Athens, Greece - A typical summer in the future climate? Global and planetary change 3-4. DOI: http://dx.doi.org/10.1016/ j.gloplacha.2009.03.013

Gilbert, R.O. 1987: Statistical methods for environmental pollution monitoring. New York.

Girardin, M. P., Ali, A. A., Carcaillet, C., Gauthier, S., Hély, C., Le Goff, H., Terrier, A., Bergeron, Y. 2013: Fire in managed forests of eastern Canada: risks and options. Forest ecology and management 294. DOI: http://dx.doi.org/10.1016/j.foreco.2012.07.005

Hrnjak, I., Lukić, T., Gavrilov, M. B., Marković, S. B., Unkašević, M., Tošić, I. 2014: Aridity in Vojvodina, Serbia. Theoretical and Applied Climatology 115. DOI: http://dx.doi.org/10.1007/s00704-013-0893-1

Intergovernmental panel on climate change, 2007. Synthesis report: contribution of working groups I, II and III to the Fourth assessment report of the Intergovernmental panel on climate change. Geneva.

Internet 1: http://www.unep.org/ (7.4.2014).

Internet 2: http://www.nfpa.org/ (23.12.2013).

Internet 3: http://www.xlstat.com/en/ (14.5.2013).

Kendall, M. 1938: A new measure of rank correlation. Biometrika 30, 1-2.

Lukić, T., Gavrilov, M. B., Marković, S. B., Komac, B., Zorn, M., Mladjan, D., Đorđević, J., Milanović, M., Vasiljević, Dj. A., Vujičić, M. D., Kuzmanović, B., Prentović, R. 2013: Classification of the natural disasters between the legislation and application: experience of the Republic of Serbia. Acta geographica Slovenica 53-1. DOI: http://dx.doi.org/10.3986/AGS53301

Mann, H. B. 1945: Non-parametric tests against trend. Econometrica 13-3.

Markov, Z., Jovičić, S., Ristić, B. 2010: Economic and ecological aspects of analysis of forest fires in Serbia. First Serbian forestry congress - future with forests. Belgrade.

Nacionalna strategija zaštite i spasavanja u vanrednim situacijama u Republici Srbiji. Službeni glasnik Republike Srbije 17/2011. Belgrade.

Onderka, M., Melicherčík, I. 2009: Spatial discretization of the Nesterov fire rating index using multispectral satellite imagery. Meteorologický časopis, 12, 2-3.

Radinović, D. 1979: Weather forecasting. Belgrade.

Republic Hydrometeorological service of Serbia 2012: Meteorological yearbook for the year 2012. Internet: http://www.hidmet.gov.rs/ (6.8.2013).

Schär, C., Vidale, P. L., Lüthi, D., Frei, C., Häberli, C., Liniger, M., Appenzeller, C. 2004: The role of increasing temperature variability in European summer heatwaves. Nature 427.

Shetinsky, E. A. 1994: Protection of forests and forest pyrology. Moscow.

Skvarenina, J., Mindas, J., Holecy, J., Tucek, J. 2003: Analysis of the natural and meteorological conditions during two largest forest fire events in the Slovak paradise national park. Forest fire in the wildland-urban interface and rural areas in Europe: an integral planning and management challenge. Athens. 
Statistical office of the Republic of Serbia 2012: Statistical yearbook of Serbia, forestry in 2011. Internet: http://pod2.stat.gov.rs/ObjavljenePublikacije/G2012/pdf/G20122007.pdf (10. 12. 2013).

Subošić, D., Mlađan, D. 2013: Main features of the fire fighting intervention carried out by the Belgrade Fire and Rescue Brigade. National Critical Infrastructure Protection Rergional Perspective. Belgrade.

Trigo, R. M., García-Herrera, R., Díaz, J., Trigo, I. F., Valente, M. A. 2005: How exceptional was the early August 2003 heatwave in France? Geophysical research letters 32. DOI: http://dx.doi.org/10.1029/ 2005GL022410

Unkašević, M., Tošić, I. 2011: The maximum temperatures and heat waves in Serbia during the summer of 2007. Climatic change 108. DOI: http://dx.doi.org/10.1007/s10584-010-0006-4

Unkašević, M., Tošić, I. 2014: Seasonal analysis of cold and heat waves in Serbia during the period 1949-2012. Theoretical and applied climatology 312. DOI: http://dx.doi.org/10.1007/s00704-014-1154-7

Willis, C., van Wilgen, B., Tolhurst, K., Everson, C., D'Abreton, P., Pero, L., Fleming, G. 2001: The development of a national fire danger rating system for South Africa. Pretoria.

Zakon o vanrednim situacijama Republike Srbije. Službeni glasnik Republike Srbije 111/2009. Belgrade.

Zakon o zaštiti od požara Republike Srbije. Službeni glasnik Republike Srbije 111/2009. Belgrade.

Zhong, M., Fan, W., Wang, Q. 2000: Experimental study in catastrophe characteristics of forest fire spread. Progress in natural science 10-6. 